\title{
Legal Status of the Self-Employed as Business Entities: Problems and prospects of Reform
}

\author{
Inna V. Ershova, Tatiana P. Shishmareva \\ and Ekaterina E. En'kova* \\ Kutafin Moscow State Law University (MSAL) \\ Moscow, Russian Federation
}

Received 27.08.2020, received in revised form 20.07.2021, accepted 14.09.2021

\begin{abstract}
The article is devoted to the study of the problems of the legal status of the self-employed as subjects of entrepreneurial activity. The legal nature of the activities of self-employed persons is studied; the self-employed are qualified as subjects of microentrepreneurship; an approach to the implementation of their bankruptcy is developed. A sociological study aimed at identifying the opinion of students about the gaps in the regulatory regulation of the legal status of the self-employed is undertaken. The correctness of the legal qualification of the self-employed as entrepreneurs is argued. The necessity of differentiation of the legal regime of activity of this category of citizens is proved. The content part of the modified concept of entrepreneurial activity is formulated. On the basis of a comparative legal analysis of the regulation of commercial and consumer insolvency in Russia and Germany, conclusions are drawn about the expediency of applying the rules of consumer insolvency to the self-employed due to their special legal status, as well as about providing them with the opportunity to continue their business activities after the completion of the bankruptcy procedure.
\end{abstract}

Keywords: self-employed, business entities, small business entities, professional income tax, insolvency, consumer bankruptcy, sociological research.

Research area: law.

Citation: Ershova, I.V., Shishmareva, T.P., En'kova, E.E. (2021). Legal status of the self-employed as business entities: problems and prospects of reform. J. Sib. Fed. Univ. Humanit. soc. sci., 14(11), 16481659. DOI: $10.17516 / 1997-1370-0847$

\footnotetext{
(C) Siberian Federal University. All rights reserved

* Corresponding author E-mail address: inna.ershova@mail.ru, tpshi@mail.ru, enkova.e.e@yandex.ru ORCID: 0000-0002-3327-6201 (Ershova); 0000-0001-7697-2533 (Shishmareva); 0000-0002-7133-6703 (En’kova)
} 


\title{
Правовой статус самозанятых
}

\section{как субъектов предпринимательства: проблемы и перспективы реформирования}

\author{
И.В. Ершова, Т.П. Шишмарева, Е.Е. Енькова \\ Московский государственный юридический университет \\ имени О.Е. Кутафина (МГЮА) \\ Российская Федеращия, Москва
}

\begin{abstract}
Аннотация. Статья посвящена исследованию проблем правового статуса самозанятых как субъектов предпринимательской деятельности. Изучена правовая природа деятельности самозанятых лиц; произведена квалификация самозанятых как субъектов микропредпринимательства; выработан подход к осуществлению их банкротства. Предпринято социологическое исследование, направленное на выявление мнения обучающихся о пробелах в нормативном регулировании правового положения самозанятых. Аргументирована правильность законодательной квалификации самозанятых в качестве предпринимателей. Обоснована необходимость дифференциации правового режима деятельности данной категории граждан. Сформулирована содержательная часть модифицированного понятия предпринимательской деятельности. На основании сравнительно-правового анализа регламентации коммерческой и потребительской несостоятельности в России и Германии сделаны выводы о целесообразности применения норм потребительской несостоятельности к самозанятым ввиду их особого правового положения, а также об обеспечении им возможности по завершении процедуры банкротства продолжить свою предпринимательскую деятельность.
\end{abstract}

Ключевые слова: самозанятые, субъекты предпринимательской деятельности, субъекты малого предпринимательства, налог на профессиональный доход, несостоятельность, потребительское банкротство, социологическое исследование.

Научная специальность: 12.00.00 - юриспруденция.

\section{Введение}

Летом 2017 г. перечень субъектов предпринимательской деятельности пополнился самозанятыми гражданами: необходимость стабильного пополнения бюджета побудила российского законодателя посулить налоговые преференции вышедшим «из тени» мелким предпринимателям. В свою очередь, правовая и социальная незащищенность подвигла последних откликнуться на предложение публичной власти. Согласно данным Федеральной налоговой службы, по состоянию на 14 декабря 2020 г. зарегистрировано 1,5 млн самозанятых, с начала 2019 г. их доход превысил 220 млрд рублей, они заплатили 4,5 млрд рублей налогов (https://www. nalog.ru/rn77/news/activities_fts/10297401/).
Очевидно, процесс пошел. Но можно ли говорить об успешном решении поставленной задачи? Как показывает правоприменительная практика, политика легализации самозанятых недостаточно эффективна, поскольку благое экономическое содержание не получило должного правового осмысления и оформления. Не определена категория самозанятости, отсутствует легальная дефиниция самозанятых лиц, не закреплены их права и гарантии, не сформирована система мер господдержки развития самозанятости.

В настоящее время главным для самозанятых является Федеральный закон от 27 ноября 2018 г. № 422-Ф3 «О проведении эксперимента по установлению 
специального налогового режима «Налог на профессиональный доход» в городе федерального значения Москве, в Московской и Калужской областях, а также в Республике Татарстан (Татарстан)». По сути, сегодня самозанятость - это, прежде всего, вопрос налоговой политики.

Ситуация правовой неопределенности побудила самую влиятельную в Госдуме РФ фракцию «Единая Россия» разработать первый вариант законопроекта о самозанятых. С учетом сжатых сроков (депутаты заявили о подготовке законопроекта до конца 2020 г.) предполагался рамочный закон, содержащий отсылки к другим нормативным правовым актам.

Проблематика самозанятости по праву может быть отнесена к числу наиболее актуальных и обсуждаемых тем не только во властных структурах, но и в обществе. Закономерно в связи с этим появление значительного числа научных и научнопублицистических исследований. Так, результатом предпринятого авторами 13 декабря 2020 г. поискового запроса «самозанятые граждане» в Научной электронной библиотеке elibrary.ru явилась 1891 публикация, из них 682 в сборниках конференций. Обращение к данным работам показывает, что чаще всего в зоне внимания оказываются такие аспекты темы, как общие вопросы (определение правового статуса, легитимация) и особенности налогообложения, причем с явным преобладанием последнего сегмента. Некоторые вопросы феномена самозанятости еще не вовлечены в оживленную научную дискуссию - к их числу относятся особенности банкротства самозанятых лиц. Обращение к библиографии позволяет выявить то, что названный предмет исследования привлекает внимание ученых разных научных специальностей - экономистов (в преобладающем числе), юристов, социологов, психологов. Как представляется, в скором будущем именно мультидисциплинарный подход позволит получить синергетический результат научных изысканий.

Важно, что, несмотря на обилие разножанровых публикаций, в доктрине не вы- работано единого понимания по ключевым позициям - правовому статусу самозанятых граждан, правовой природе их деятельности. А это, в свою очередь, влечет появление более частных вопросов, например, относительно возможности приобретения самозанятыми статуса субъектов малого предпринимательства.

На основании изложенного можно сделать вывод о необходимости глубокого научного осмысления правового положения самозанятых с целью достижения доктринального единообразия, а также выработки предложений, адресованных законодателю и правоприменителю.

\section{Постановка проблемы}

Спектр теоретико-прикладных проблем, порожденных введением в российское законодательство правового режима деятельности самозанятых, весьма широк. Не претендуя на их полный охват, остановимся на вопросах, по которым у авторов имеются предложения, в силу научной новизны и практической значимости способные представлять интерес для профессиональной общественности.

В фокусе нашего внимания, учитывая обозначенный фильтр, оказались следующие конкретные проблемы:

- выявление правовой природы деятельности самозанятых лиц с учетом ее единства и дифференциации;

- определение места самозанятых среди субъектов малого предпринимательства;

- установление правил для осуществления банкротства самозанятых.

\section{Методология}

Методологическую основу исследования составили следующие методы научного познания: анализ, синтез, дедукция, интерпретация, прогнозирование, а также компаративистский и социологический методы. Метод компаративистики был использован при анализе правового положения самозанятого в отношениях несостоятельности в целях сравнительного анализа положений законодательства России и Германии применительно к субъектам экономической 
деятельности. Методом анкетирования авторы в 2020 г. провели социологическое исследование «Самозанятые как субъекты предпринимательской деятельности», где в ходе целенаправленной выборки респондентами выступили 54 обучающихся бакалавриата и 26 студентов магистерской программы «Правовое сопровождение бизнеса (бизнес-юрист)» Университета имени О.Е. Кутафина (МГЮА). Данное социологическое исследование можно охарактеризовать как повторное. Первое состоялось в 2017 г. и было проведено также методом анкетирования 300 студентов и аспирантов МГЮА.

\section{Обсуждение}

\section{Самозанятые: единство}

\section{и дифференциация правового статуса}

Формирование правового режима деятельности самозанятых граждан происходит поэтапно и уже ознаменовалось серьезной корректировкой отдельных положений кодифицированных законодательных актов. При этом стартовая правовая модель государственного регулирования деятельности самозанятых граждан не была упразднена с появлением второй.

Напомним, что первым шагом на этом пути стало принятие Федерального закона от 30 ноября 2016 г. № 401-ФЗ «О внесении изменений в части первую и вторую Налогового кодекса Российской Федерации и отдельные законодательные акты Российской Федерации», позволившего физическим лицам, оказывающим услуги физическим лицам для личных, домашних и (или) иных подобных нужд без привлечения наемных работников (п. 70 ст. 217 НК РФ) осуществлять данную деятельность не будучи зарегистрированными в качестве индивидуальных предпринимателей. Их легитимация осуществляется в уведомительном режиме путем подачи заявления в налоговые органы. Указанный вариант обретения самозанятыми легального статуса существует и сегодня. По данным Федеральной налоговой службы (https://www.nalog.ru/rn77/ related_activities/statistics_and_analytics/ selfemployed/), по состоянию на 1 июля
2020 г. число самозанятых граждан, представивших в налоговые органы уведомления об осуществлении деятельности по оказанию услуг физическому лицу, составило 4448 , из них по присмотру и уходу за детьми, больными лицами, лицами, достигшими возраста 80 лет, а также иными лицами, нуждающимися в постоянном постороннем уходе по заключению медицинской организации,- 589, по репетиторству - 2870, по уборке жилых помещений, ведению домашнего хозяйства - 734, иные виды услуг, установленные законом субъекта РФ,- 538.

Перечисленные нововведения повлекли за собой дискуссию относительно правовой природы деятельности выведенных из тени предпринимателей. Как было указано, авторами в 2017 г. было проведено первое социологическое исследование. Определяя правовую природу социальной активности самозанятых граждан, респонденты отдали явное предпочтение ее квалификации в качестве приносящей доход деятельности (65\%). С большим отрывом следуют предложения рассматривать деятельность указанных лиц как предпринимательскую (26 \%), трудовую (23\%) либо иную экономическую (13,3%) (Ershova, Trofimova, 2017).

Заметим, что анкетирование состоялось в преддверии внесения изменений в Гражданский кодекс РФ. Представляя законопроект о внесении изменений в статьи 2 и 23 данного Кодекса, П.В. Крашенинников образно сравнил их с открытием шлагбаума и снятием решеток для уведомивших о себе налоговые органы самозанятых и призвал их в армию предпринимателей.

Однако при формировании правовых норм не были учтены неоднократно высказываемые в доктрине предостережения о том, что до четкого закрепления правового статуса самозанятых граждан попытки их легализации представляются обреченными на неуспех (Ershova, Trofimova, Davtyan-Davudova, Kochetkova, 2019). В целом мы согласны с учеными, обращавшими внимание на противоречия теории и практики при обновлении норм Гражданского 
кодекса РФ (Inshakova, Goncharov, Mineev, Sevostyanov, 2017).

Неполучение желаемых количественных показателей, иные причины «пробуксовки» вывода из тени нелегалов подвигли законодателя к выработке новых правовых моделей взаимодействия самозанятых и государства.

С 1 января 2019 г. вступил в силу Федеральный закон от 27 ноября 2018 г. № 422-Ф3 «О проведении эксперимента по установлению специального налогового режима «Налог на профессиональный доход» в городе федерального значения Москве, в Московской и Калужской областях, а также в Республике Татарстан (Татарстан)». Причем заявленный в качестве экспериментального указанный налоговый режим с первых месяцев применения положительно себя зарекомендовал, что послужило основанием для его распространения на большую часть территории России.

Закон 2019 г. придал новый импульс обсуждению правовой природы деятельности самозанятых граждан - дискуссия, несколько утихшая после причисления Гражданским кодексом РФ самозанятых к предпринимателям, возобновилась с новой силой. К примеру, О.А. Тарасенко полагает более точным квалифицировать их деятельность в качестве профессиональной приносящей доход, нежели предпринимательской (Tarasenko, 2020).

Принимая во внимание данное мнение, все же не считаем возможным его поддержать. Признание активности самозанятых в качестве приносящей доход деятельности не позволяет провести ее отграничение от деятельности некоммерческих организаций и в целом демонстрирует отсутствие корреляции с положениями Гражданского кодекса РФ. Помимо этого, рассматриваемая позиция грешит смешением двух характеристик («профессиональная» и «приносящая доход»), что явно затрудняет квалификацию.

Не имея возможности изложить все имеющиеся в доктрине позиции, позволим себе обнародовать собственный вывод. Полагаем, что деятельность самозанятых по своей правовой природе является предпринимательской. Вместе с тем подобная квалификация требует дополнительных законодательных изменений.

Так, основной целью предпринимательской деятельности служит направленность на систематическое получение прибыли это следует из законодательной дефиниции статьи 2 Гражданского кодекса РФ. Однако применительно к самозанятым, равно как и к индивидуальным предпринимателям, речь идет о получении и последующем налогообложении дохода. Отметим, что переход к учету в качестве финансового показателя деятельности предпринимателей предусмотрен и иными законодательными актами, например Федеральным законом от 24 июля 2007 г. № 209-Ф3 «О развитии малого и среднего предпринимательства в Российской Федерации» для получения статуса малого или среднего предприятия.

Одним из признаков предпринимательской деятельности является самостоятельность предпринимателя. Наличие таковой у некоторых категорий самозанятых (например, оказывающих услуги по присмотру и уходу за детьми, больными лицами, по ведению домашнего хозяйства и др.) вызывает большое сомнение. Очевидно, что необходима дифференциация правового статуса самозанятых, ведущих собственное дело, и «зависимых» самозанятых, работающих на конкретное лицо.

Важно и то, что в легальном определении предпринимательской деятельности содержится исчерпывающий перечень возможных для ее осуществления направлений. Спектр деятельности самозанятых позволяет говорить о выходе за его пределы. Для примера приведем востребованный самозанятыми вид деятельности - сдачу в аренду жилого помещения. Будучи актом реализации такого правомочия собственника, как распоряжение имуществом, указанный вид социальной активности не укладывается в «прокрустово ложе» официального определения предпринимательства.

В качестве промежуточного вывода исследования сформулируем посыл законодателю об изменении закрепленного 
в Гражданском кодексе РФ понятия предпринимательской деятельности с целью приведения его в соответствие со сложившимися реалиями, в том числе и в связи с формированием правового института самозанятости.

Следует обратить внимание также на то, что условием ведения многих видов предпринимательской деятельности является, помимо государственной регистрации, выполнение субъектами определенных требований. Так, ограничения и запреты, связанные с личностью самого физического лица, зачастую предъявляются при получении лицензии либо вступлении в саморегулируемую организацию (Shishko, Demyanenko, 2011). Применительно к самозанятым таковых не установлено. Для сравнения напомним, что согласно статье 331 Трудового кодекса РФ к педагогической деятельности не допускаются лица, имеющие или имевшие судимость, подвергавшиеся уголовному преследованию за преступления против жизни и здоровья, свободы, чести и достоинства личности, половой неприкосновенности и половой свободы личности, против семьи и несовершеннолетних и др. Но для занятия, например, репетиторством в качестве самозанятого гражданину с таким уголовным прошлым путь открыт. Ситуация вызывает обеспокоенность и недоумение.

Аспект правовой природы самозанятости неизбежно подводит к вопросу о возможности квалификации самозанятых в качестве субъектов малого предпринимательства. Поскольку нами уже приводились аргументы для положительного ответа на данный вопрос (Ershova, Tarasenko, 2018), позволим себе лишь подтвердить сделанный ранее вывод о необходимости законодательного расширения потенциальных субъектов микропредпринимательства за счет самозанятых граждан. Дополнение Федерального закона от 24 июля 2007 г. № 209-Ф3 «О развитии малого и среднего предпринимательства в Российской Федерации» статьей 14.1 «Поддержка физических лиц, не являющихся индивидуальными предпринимателями и применяющих специальный налоговый режим «Налог на профессиональный доход»») явно не выглядит достаточным. Указанные изменения можно считать лишь первым шагом на пути обретения самозанятыми гражданами статуса субъекта микропредпринимательства. Но только теми из них, деятельность которых будет отвечать всем закрепленным в законе признакам предпринимательской деятельности - надеемся, что в модифицированном виде.

В целом сказанное позволяет подтвердить позицию, согласно которой в силу явной разнохарактерности деятельности самозанятых граждан необходима дифференциация их правового статуса. Российскому законодателю надлежит провести более четкое разграничение между подлинно самозанятыми и мелкими предпринимателями, с одной стороны, и наемными работниками - с другой.

\section{Банкротство самозанятых}

Анализируя положения главы X Федерального закона от 26 октября 2002 г. № 127Ф3 «О несостоятельности (банкротстве)» (далее - Закон о банкротстве) о субъектах, которые включены в круг граждан, необходимо указать, что в ней не обозначены особенности банкротства самозанятых, хотя для индивидуальных предпринимателей они предусмотрены в 22 и 3 данной главы.

В научной литературе представлены различные точки зрения по вопросу о банкротстве самозанятых. Высказано мнение, что банкротство названных субъектов следует осуществлять по правилам главы $\mathrm{X}$ Закона о банкротстве с учетом особенностей, установленных для индивидуальных предпринимателей статьей 213.1 названного Закона. При этом следует распространить на них обязанности и ограничения, действующие в отношении индивидуальных предпринимателей (Korbu, 2019).

Встречается позиция о дополнении главы X Закона о банкротстве $\S 3.1$, в котором будут установлены особенности признания самозанятых несостоятельными, в том числе специальные основания признания их несостоятельными и правовые послед- 
Inna V. Ershova, Tatiana P. Shishmareva... Legal Status of the Self-Employed as Business Entities: Problems...

ствия, например утрата статуса самозанятого, отмена налоговых льгот (Skvortsova, Glugovskaia, Troitskaia, 2018).

Изложим свое видение данного аспекта рассматриваемой проблематики. По своему правовому положению самозанятые отличаются от индивидуальных предпринимателей, поскольку они зачастую занимаются предпринимательской деятельностью в незначительных размерах либо по существу ее трудно назвать предпринимательской. У самозанятых среди кредиторов не может быть работников, поскольку они не имеют права заключать трудовые договоры. У них незначительный размер конкурсной массы или она вовсе отсутствует. В связи с этим возникает проблема квалификации их банкротства в качестве коммерческого или потребительского. Правовое регулирование коммерческого и некоммерческого банкротства различается главным образом правовыми последствиями, что применительно к самозанятым имеет существенное значение.

С одной стороны, самозанятые граждане, которые встали на налоговый учет, признаются предпринимателями согласно абзацу 3 пункта 1 статьи 2, абзацу 2 пункта 1 статьи 23 Гражданского кодекса РФ. C учетом правового статуса самозанятых их необходимо признавать банкротами по тем же правилам, что и индивидуальных предпринимателей, по аналогии закона, поскольку имеются условия для ее применения: а) в законодательстве имеется пробел в правовом регулировании банкротства самозанятых; б) сходство регулируемых отношений.

С другой стороны, самозанятые по своему правовому положению, особенно некоторая их часть, занятая оказанием бытовых услуг, являются по существу наемными работниками, а не предпринимателями. Весьма сложно разграничить в этом случае потребительское и коммерческое банкротство, цели правовой политики государства в рассматриваемой сфере весьма неопределенны. Если государство стремится предоставить возможность нового старта самозанятым в случае их банкротства, то коммерческая модель не позволит их достичь, так как по окончании процедуры банкротства вводится запрет на предпринимательскую деятельность в течение пяти лет.

В судебной практике пока не сложилось определенной позиции ввиду незначительности случаев признания самозанятых банкротами. В отдельных судебных актах (например, в постановлении Семнадцатого арбитражного апелляционного суда от 11 сентября 2020 г. № 17АП-8205/2020 (21)-АК по делу № А50-36309/2019) самозанятых не признают предпринимателями, применяют к ним правила потребительской, а не коммерческой несостоятельности.

Кроме того, в постановлении Арбитражного суда Восточно-Сибирского округа от 4 августа 2020 г. № Ф02-2554/2020 по делу № А33-894/2019 имеются ссылки на самозанятость как источник дополнительного дохода для гражданинапотребителя. В этом случае при признании такого гражданина банкротом кредиторы из предпринимательских и потребительских правоотношений вправе предъявить требования к должнику в рамках единого производства по делу о банкротстве, поскольку законодательством не предусмотрено введение двух производств. Правовая позиция Верховного Суда РФ по данному вопросу содержится в пункте 2 постановления Пленума Верховного Суда РФ от 13 октября 2015 г. № 45.

Представляет интерес и проблема квалификации правоотношений банкротства, если самозанятые не имеют соответствующего статуса, поскольку не встали на налоговый учет, однако занимаются приносящей доход деятельностью. Аналогичная проблема обсуждается в доктрине в отношении индивидуальных предпринимателей, которые занимаются незаконной предпринимательской деятельностью. В.Н. Ткачев признает возможность введения процедуры банкротства в отношении гражданина как индивидуального предпринимателя при отсутствии государственной регистрации (Tkachev, 2007). В судебной практике специ- 
альный режим коммерческого банкротства применяется только при условии легализации индивидуального предпринимателя, хотя субъекты вправе при этом получить льготы и преимущества как потребители, что не представляется верным для индивидуального предпринимателя. Применение для субъектов, занимающихся незаконной предпринимательской деятельностью, правил о потребительском банкротстве представляется в корне ошибочным решением правоприменителей.

Учитывая, что самозанятый, как правило, получает незначительный доход, не имеет в качестве кредиторов работников, права которых требуют особой защиты, у него малое число кредиторов, поскольку он самостоятельно обеспечивает свою деятельность в качестве особого субъекта экономических отношений, полагаем вполне допустимым признавать его банкротом в качестве потребителя до внесения изменений в Закон о банкротстве.

Обратимся к опыту правового регулирования несостоятельности предпринимателей и потребителей в Германии. Так, в течение 1999-2001 гг. субъектов, которые занимались хозяйственной деятельностью в незначительных размерах, признавали несостоятельными как потребителей. Затем немецкий законодатель отказался от такой практики - 26 октября 2001 г. в § 304 Insolvenzordnung внесены изменения Gesetz zum Änderung der Insolvenzordnung und andere Gesetze. В настоящее время к названным субъектам применяются правила о коммерческой несостоятельности. Вместе с тем по правилам потребительской несостоятельности признают банкротами предпринимателей, утративших свой статус, при определенных условиях: имущественные отношения являются обозримыми, т. е. масштабы деятельности незначительны; против них отсутствуют требования работников из трудовых отношений; их самостоятельная хозяйственная деятельность к моменту введения процедуры должна быть полностью прекращена (Hamburger Kommentar zum Insolvenzrecht, 2009; Insolvenzordnung (InsO). Kommentar, 2017).
Применительно к российской правовой действительности представляется необходимым внести в Закон о банкротстве изменения, предусмотрев для самозанятых особые правовые последствия банкротства, которые должны отличаться от коммерческого банкротства тем, что добросовестный самозанятый вправе продолжить свою деятельность по окончании процедуры, освободившись от долгов, которые он оказался не в состоянии погасить.

\section{Правовой статус самозанятых через призму социологического исследования}

Актуальность исследуемой проблематики обусловила стремление выяснить позицию студентов. Арсенал эмпирической социологии активно применяется в образовательной среде при проведении теоретических и прикладных исследований. Уже упоминалось, что в 2020 г. авторами статьи было предпринято социологическое исследование «Самозанятые как субъекты предпринимательской деятельности». Результаты анкетирования приведены в табл. 1.

Перечень субъектов предпринимательской деятельности в 2017 г. был расширен за счет включения в него самозанятых лиц. Большинство опрошенных $(83,75$ \%) поддержали российского законодателя в его стремлении легализовать названную категорию граждан, и лишь 16,25 \% негативно оценили такое нормативное решение.

На всех уровнях - в государственных структурах, в общественных кругах, в научной среде - активно дискутировался вопрос о видах активности, занятие которыми позволяет лицу получить статус самозанятого. В результате позиция законодателя по данному вопросу кардинально изменилась: вместо закрытого перечня, включающего всего три вида деятельности, был закреплен принцип «Разрешено все, что не запрещено законом». Две трети респондентов $(66,25 \%)$, положительно оценив подобный тренд, полагают, что перечень должен быть открытым. По мнению одной трети (32,5\%), закрытый перечень в силу определенности выглядит предпочтительнее. Один из участвующих в анкетирова- 
Таблица 1. Самозанятые как субъекты предпринимательской деятельности

Table 1. Self-employed as business entities

\begin{tabular}{|c|c|c|c|}
\hline Вопрос $\quad$ Уровень образования & $\begin{array}{l}\text { Бакалавриат } \\
54\end{array}$ & $\begin{array}{l}\text { Магистратура } \\
26\end{array}$ & $\begin{array}{l}\text { Итого } \\
80\end{array}$ \\
\hline $\begin{array}{l}\text { 1. Вы разделяете позицию законодателя о признании } \\
\text { самозанятых субъектами предпринимательской дея- } \\
\text { тельности? } \\
\text { А) Да } \\
\text { Б) Нет }\end{array}$ & $\begin{array}{l}\text { A } 47 \\
\text { Б } 7\end{array}$ & $\begin{array}{l}\text { A } 20 \\
\text { Б } 6\end{array}$ & $\begin{array}{l}\text { A } 67 \\
\text { Б } 13\end{array}$ \\
\hline $\begin{array}{l}\text { 2. Как надлежит сформулировать перечень видов де- } \\
\text { ятельности, которыми могут заниматься самозаня- } \\
\text { тые?' } \\
\text { А) Перечень видов деятельности должен быть закрытым } \\
\text { Б) Перечень видов деятельности должен быть открытым }\end{array}$ & A 21 & А 5 & $\begin{array}{l}\text { А } 26 \\
\text { Б } 53\end{array}$ \\
\hline $\begin{array}{l}\text { 3. Целесообразно ли наделять самозанятых правом } \\
\text { привлекать работников? } \\
\text { А) Да } \\
\text { Б) Нет }\end{array}$ & $\begin{array}{l}\text { A } 18 \\
\text { Б } 36\end{array}$ & $\begin{array}{l}\text { A } 7 \\
\text { Б } 19\end{array}$ & $\begin{array}{l}\text { A } 25 \\
\text { Б } 55\end{array}$ \\
\hline $\begin{array}{l}\text { 4. Оправданно ли, что специальный налоговый ре- } \\
\text { жим «Налог на профессиональный доход» наряду с } \\
\text { самозанятыми могут применять индивидуальные } \\
\text { предприниматели? } \\
\text { А) Да } \\
\text { Б) Нет } \\
\text { В) Затрудняюсь ответить }\end{array}$ & $\begin{array}{l}\text { A } 21 \\
\text { Б } 19 \\
\text { В } 14\end{array}$ & $\begin{array}{l}\text { A } 10 \\
\text { Б } 8 \\
\text { В } 8\end{array}$ & $\begin{array}{l}\text { A } 31 \\
\text { Б } 27 \\
\text { В } 22\end{array}$ \\
\hline $\begin{array}{l}\text { 5. Какие налоговые льготы являются оптимальными } \\
\text { для самозанятых?를 } \\
\text { А) Налоговые каникулы продолжительностью } 5 \text { лет } \\
\text { Б) Ставка по налогу на профессиональный доход должна } \\
\text { быть ниже, чем у индивидуальных предпринимателей } \\
\text { В) Иное (укажите) }\end{array}$ & \begin{tabular}{|} 
А 10 \\
Б 45 \\
В 1 \\
ничего не \\
предложено
\end{tabular} & $\begin{array}{c}\text { А } 9 \\
\text { Б } 17 \\
\text { В 1 } \\
\text { ставка по налогу не бо- } \\
\text { лее 5 \% с прибыли (до- } \\
\text { ходы минус расходы) и } \\
\text { налоговые каникуль } 3 \\
\text { года с возможностью } \\
\text { дальнейшего продления } \\
\text { (в зависимости от эко- } \\
\text { номической ситуачии в } \\
\text { стране) }\end{array}$ & $\begin{array}{l}\text { А } 19 \\
\text { Б } 62 \\
\text { В } 2\end{array}$ \\
\hline $\begin{array}{l}\text { 6. Нужно ли признавать самозанятых субъектами ма- } \\
\text { лого предпринимательства? } \\
\text { А) Да } \\
\text { Б) Нет }\end{array}$ & $\begin{array}{l}\text { A } 36 \\
\text { Б } 18\end{array}$ & $\begin{array}{l}\text { A } 18 \\
\text { Б } 8\end{array}$ & $\begin{array}{l}\text { А } 54 \\
\text { Б } 26\end{array}$ \\
\hline $\begin{array}{l}\text { 7. Как должно осуществляться банкротство самозаня- } \\
\text { тых? } \\
\text { А) По общим правилам, установленным для признания } \\
\text { банкротом гражданина } \\
\text { Б) С учетом особенностей, предусмотренных для бан- } \\
\text { кротства индивидуального предпринимателя } \\
\text { В) Необходимо разработать специальные правила бан- } \\
\text { кротства самозанятых }\end{array}$ & $\begin{array}{l}\text { A } 11 \\
\text { Б } 11 \\
\text { В } 32\end{array}$ & $\begin{array}{l}\text { A } 11 \\
\text { Б } 6 \\
\text { В } 9\end{array}$ & $\begin{array}{l}\text { А } 22 \\
\text { Б } 17 \\
\text { В } 41\end{array}$ \\
\hline
\end{tabular}

1 По данному вопросу один респондент-бакалавр не дал ответа.

2 По данному вопросу 3 респондента (2 бакалавра и 1 магистрант) выбрали одновременно варианты ответа «а» и «б». 
нии бакалавров уточнил, что если и формулировать перечень как исчерпывающий, то он должен быть достаточно подробным.

Самозанятые хотя и признаны субъектами предпринимательской деятельности, однако в отличие от юридических лиц и индивидуальных предпринимателей не вправе привлекать наемных работников. С таким подходом солидарны $68,75 \%$ опрошенных, поскольку он позволяет дифференцировать упомянутые категории лиц, занимающихся бизнесом. За равенство всех названных субъектов в указанном аспекте выступили 31,25 \% респондентов.

Законодатель распространил специальный налоговый режим «Налог на профессиональный доход» и на самозанятых, и на индивидуальных предпринимателей. Ответ на вопрос об оправданности такого подхода у 27,5 \% опрошенных вызвал затруднение. Позитивные и негативные оценки обучающихся разделились почти поровну, с незначительным перевесом в пользу первых - 38,75 против 33,75 \%.

Важным стимулом для легализации самозанятых является предоставление соответствующих налоговых льгот. Данный вопрос в анкете был сформулирован как открытый: студенты могли озвучить свое мнение по поводу значимых льгот для самозанятых, но проявили инертность и не воспользовались предоставленной возможностью. Двое обучающихся (2,5 \%) выбрали вариант ответа «Иное», при этом лишь один из них высказался определенно. Налоговые каникулы продолжительностью 5 лет сочли оптимальной мерой государственной поддержки 23,75 \% опрошенных. Подавляющее число респондентов (77,5\%) проголосовали за установление в отношении самозанятых более низкой в сравнении с индивидуальными предпринимателями ставки по налогу на профессиональный доход, очевидно, восприняв данную меру как более стабильную и не ограниченную во времени.

С целью поддержания деловой активности самозанятых в научной литературе предлагается признать их субъектами малого предпринимательства. Однако зако- нодатель не торопится придать правовую форму доктринальным суждениям. Результаты анкетирования показали, что существенная часть опрошенных (67,5\%) ратует за нормативное закрепление подобного предложения. Тем не менее треть опрошенных $(32,5$ \%) видят это нецелесообразным.

Значительный исследовательский интерес представляет вопрос о правовом режиме банкротства самозанятых. Вопросы несостоятельности самозанятых в силу непродолжительного существования названных субъектов в экономическом обороте и недостаточной определенности их правового статуса в настоящее время не урегулированы. Указанное обстоятельство усилило желание выяснить позиции обучающихся. Так, более половины опрошенных $(51,25 \%)$ заявили о необходимости разработки специальных правил банкротства самозанятых. По мнению $27,5 \%$ респондентов, в отношении названных субъектов надлежит применять общие правила, установленные для признания банкротом гражданина. За учет особенностей, предусмотренных для банкротства индивидуального предпринимателя, высказалось $21,25 \%$ участников анкетирования.

Полагаем, что проведение подобных социологических исследований способствует трансформации обучающихся из участников в менеджеров образовательных проектов (Cano-Moreno, Arenas, Sánchez, Islán, Narbón, 2019) и, как следствие, повышает эффективность учебного процесса.

\section{Заключение}

Проведенное авторами исследование позволяет, во-первых, поддержать правильность законодательной квалификации самозанятых в качестве предпринимателей; во-вторых, обосновать необходимость дифференциации соответствующего правового режима. Что же касается модифицированного понятия предпринимательской деятельности, то его содержательная часть может быть сформулирована следующим образом: предпринимательской является самостоятельная, осуществляемая на свой риск деятельность, направленная на систе- 
матическое получение прибыли или дохода от не запрещенной законом деятельности.

Авторами аргументирована позиция о целесообразности признания самозанятого банкротом по правилам, предусмотренным для гражданина-потребителя, ввиду особого правового положения самозанятого. Предлагается внести изменения в Закон о банкротстве, чтобы четко закрепить данный постулат, а также установить специальное правовое последствие для добросовестных самозанятых - продолжение ими предпринимательской деятельности после завершения процедуры банкротства с целью обеспечения возможности нового старта.

\section{Список литературы / References}

Ershova, I.V., Trofimova, E.V. (2017). Samozaniatost': repernye tochki formirovaniia pravovogo rezhima [Self-Employment: Reference Points of Legal Regime Forming], In Predprinimatel'skoe parvo [Business Law], 3, 3-12.

Ershova, I.V., Tarasenko, O.A. (2018). Maloe i srednee predprinimatel'stvo: transformatsia rossiiskoi sistemy kreditovaniia i mikrofinansirovaniia [Small and Medium-Sized Enterprises: Transformation of the Russian Crediting and Microfinancing System]. In Vestnik Permskogo Universiteta. Iuridicheskie Nauki [Perm University Herald. Juridical Sciences], 39, 99-124. DOI: 10.17072/1995-4190-2018-39-99-124.

Ershova, I.V., Trofimova, E.V., Davtyan-Davudova, D. \& Kochetkova, S.Y. (2019). Legal Routes of Legitimation of Self-employed Citizens and Other Business Entities in the Context of the Public Services Digitization. In Studies in Computational Intelligence, 826, 153-162. DOI: 10.1007/978-3-030-13397-9 18

Federal'nyi zakon ot 26 oktiabria 2002 g. № 127-FZ «O nesostoiatel'nosti (bankrotstve)» [Federal Law No. 127-FZ of October 26, 2002 «On Insolvency (Bankruptcy)»]. Available at: http://www.consultant. ru/document/cons doc LAW 39331/(accessed 20 December 2020).

Federal'nyi zakon ot 24 iiulia 2007 g. № 209-FZ «O razvitii malogo i srednego predprinimatel'stva $v$ Rossiiskoi Federatsii» [Federal Law № 209-FZ of July 24, 2007 «On the Development of Small and Medium-Sized Enterprises in the Russian Federation»] Available at: http://www.consultant.ru/document/ cons doc_LAW 52144/ (accessed 20 December 2020).

Federal'nyi zakon ot 30 noiabria 2016 g. № 401-FZ «O vnesenii izmenenii v chasti pervuiu $i$ vtoruiu Nalogovogo kodeksa Rossiiskoi Federatsii i otdel'nye zakonodatel'nye akty Rossiiskoi Federatsii [Federal Law № 401-FZ of November 30, 2016 «On Amendments to Parts One and Two of the Tax Code of the Russian Federation and Certain Legislative Acts of the Russian Federation»]. Available at: http://www. pravo.gov.ru, 30.11.2016 (accessed 20 December 2020).

Federal'nyi zakon ot 27 noiabria 2018 g. № 422-FZ «O provedenii eksperimenta po ustanovleniiu spetsial'nogo nalogovogo rezhima «Nalog na professional'nyi dohod» $v$ gorode federal'nogo znacheniia Moskve, v Moskovskoi i Kaluzhskoi oblastiakh, a takzhe v Respublike Tatarstan (Tatarstan)» [Federal Law № 422-FZ of November 27, 2018 «On conducting an experiment to establish a special tax regime «Tax on Professional Income» in the Federal City of Moscow, in the Moscow and Kaluga Regions, as well as in the Republic of Tatarstan (Tatarstan)»] Available at: http://www.pravo.gov.ru, 27.11.2018 (accessed 20 December 2020).

Federal Tax Service (2020). Available at: https://www.nalog.ru/rn77/related_activities/statistics_and_ analytics/selfemployed/ (accessed 20 December 2020).

Federal Tax Service (2020). Available at: https://www.nalog.ru/rn77/news/activities_fts/10297401/ (accessed 20 December 2020).

Gesetz zum Änderung der Insolvenzordnung und andere Gesetze vom 26.10.2001. Bundesgesetzblatt Jahrgang 2001. Teil 1 № 54. Ausgegeben zu Bonn am 31 Oktober 2001. Available at: https://www.bgbl.de (accessed 20 December 2020).

Grazhdanskii kodeks Rossiiskoi Federatsii ot 30 noiabria 1994 g. № 51-FZ [Civil Code of the Russian Federation № 51-FZ of November 30, 1994]. Available at: http://www.consultant.ru/document/cons_doc_ LAW_5142/(accessed 20 December 2020). 
Hamburger Kommentar zum Insolvenzrecht. (2009). Herausgegeben von Dr. Andreas Schmidt 3 Auflage.Münster, ZAP-Verlag, $2010 \mathrm{p}$.

Inshakova, A.O., Goncharov, A.I., Mineev, O.A., \& Sevostyanov, M.V. (2017). Amendments to the Civil Code of the Russian Federation: Contradictions of theory and practice. In Russia and the European Union: Development and Perspectives. Contributions to economics, 13, 147-153. DOI: 10.1007/978-3-31955257-6_20

Insolvenzordnung (InsO). Kommentar. (2017). Herausgegeben von Eberhard Braun. 7., neu bearbeitete Auflage. München, Verlag C.H. Beck, 2060 p.

Juan David Cano-Moreno, José M. Arenas, Victoria Sánchez, Manuel Islán, Julián Narbón. (2019). Methodology for quantitative evaluation of university teaching. Application to the subject of Project Management. Procedia Manufacturing. Volume 41, 930-937. https://doi.org/10.1016/j.promfg.2019.10.017

Korbu, IU.I. (2019). Osobennosti bankrotstva samozaniatykh grazhdan: perspektivy pravovogo regulirovaniia [Features of bankruptcy of self-employed citizens: prospects of legal regulation]. Pravovye sredstva stimulirovaniia aktivnoi zaniatosti i povisheniia konkurentosposobnosti na rynke truda: sbornik nautnykh statei [Legal means of stimulating active employment and increasing competitiveness in the labor market: collection of scientific articles], Tiumen', 121-126.

Nalogovyi kodeks Rossiiskoi Federatsii ot 1 iiulia 1998 g. № 146-FZ [Tax Code of the Russian Federation № 146-FZ of November 1, July 1998]. Available at: http://www.consultant.ru/document/cons doc_LAW_19671/ (accessed 20 December 2020).

Postanovlenie Plenuma Verkhovnogo Suda RF № 45 ot 13 oktiabria 2015 «O nekotorykh voprosakh, sviazannykh s vvedeniem $\mathrm{v}$ deistvie protsedur, primeniaemykh $\mathrm{v}$ delakh o nesostoiatel'nosti (bakrotstve) grazhdan» [Resolution of the Plenum of the Supreme Court of the Russian Federation No. 45 of Oktober 13, 2015 «On some issues related to the introduction of procedures used in cases of insolvency (bankruptcy) of citizens»]. Available at: http://www.vsrf.ru/documents/own/8455/ (accessed 20 December 2020).

Shishko, I.V., Demyanenko, E.V. (2011). Criminal-Legal and Administrative-Legal Means of Ensuring Economic Activity Self-Regulation in Russian Federation. In Journal of Siberian Federal University. Humanities \& Social Sciences, 4 (2), 158-164.

Skvortsova, T.A., Glugovskaia, K.A., Troitskaia, IU.A. (2018). Nekotorye voprosy nesostoiatel'nosti (bankrotstva) grazhdan-predprinimatelei i kommerteskikh iuriditeskikh lits [Some issues of insolvency (bankruptcy) of citizens-entrepreneurs and commercial legal entities]. Nauka i obrazovanie: khoziaistvo i ekonomika; predprinimatel'stvo; parvo i upravlenie [Science and education: economy and economics; entrepreneurship; law and management], № 7 (98), 100-103.

Tarasenko, O.A. (2020). IA b v samozaniatye poshel, pust' menia nauchat [I Would Become a SelfEmployed, Let Them Teach Me!]. In Predprinimatel'skoe parvo [Business Law], 3, $27-33$.

Tkachev, V.N. (2007). Nesostoiatel'nost' (bankrotstvo) osobykh kategorii sub"ektov konkursnogo prava: teoreticheskie i prakticheskie problemy pravovogo regulirovaniia [Insolvency (bankruptcy) of special categories of subjects of competition law: theoretical and practical problems of legal regulation]. Moscow, Wolters Kluwer, 368 p.

Trudovoi kodeks Rossiiskoi Federatsii ot 30 dekabria 2001 g. № 197-FZ [Labor Code of the Russian Federation № 197-FZ of December 30, 2011]. Available at: http://www.consultant.ru/document/cons_doc_ LAW_34683/ (accessed 20 December 2020). 